Article

\title{
The Decrease of Leaf Dark Respiration during Water Stress Is Related to Leaf Non-Structural Carbohydrate Pool in Vitis vinifera L.
}

\author{
Sergio Tombesi ${ }^{1, *(\mathbb{C})}$, Tommaso Frioni ${ }^{1}{ }^{(\mathbb{C}}$, Francesca Grisafi ${ }^{1}$, Paolo Sabbatini ${ }^{2}{ }^{\circledR}$, Stefano Poni ${ }^{1}(\mathbb{C}$ \\ and Alberto Palliotti ${ }^{3}$ \\ 1 Department of Sustainable Crop Production, Università Cattolica del Sacro Cuore, Via Emilia Parmense 84, \\ 29122 Piacenza, Italy; tommaso.frioni@unicatt.it (T.F.); francesca.grisafi1@unicatt.it (F.G.); \\ stefano.poni@unicatt.it (S.P.) \\ 2 Department of Horticulture, Michigan State University, 1066 Bogue Street, East Lansing, MI 48824, USA; \\ sabbatin@msu.edu \\ 3 Department of Agricultural, Food and Environmental Sciences, Università degli Studi di Perugia, \\ Borgo 20 Giugno 74, 06154 Perugia, Italy; alberto.palliotti@unipg.it \\ * Correspondence: sergio.tombesi@unicatt.it; Tel.: +39-0523-599-221
}

Citation: Tombesi, S.; Frioni, T.; Grisafi, F.; Sabbatini, P.; Poni, S.; Palliotti, A. The Decrease of Leaf Dark Respiration during Water Stress Is Related to Leaf Non-Structural Carbohydrate Pool in Vitis vinifera L. Plants 2022, 11, 36. https://doi.org/ $10.3390 /$ plants 11010036

Academic Editor: Fulai Liu

Received: 3 December 2021

Accepted: 21 December 2021

Published: 23 December 2021

Publisher's Note: MDPI stays neutral with regard to jurisdictional claims in published maps and institutional affiliations.

Copyright: (C) 2021 by the authors. Licensee MDPI, Basel, Switzerland. This article is an open access article distributed under the terms and conditions of the Creative Commons Attribution (CC BY) license (https:// creativecommons.org/licenses/by/ $4.0 /)$.

\begin{abstract}
Dark respiration $\left(\mathrm{R}_{\mathrm{d}}\right)$ is a fundamental plant process used to gain biomass and maintain plant physiological activity. It accounts for the metabolization of a large share of the carbon fixed by photosynthesis. However, $R_{d}$ during conditions of severe plant water stress is still poorly understood. The decrease in leaf transpiration increases temperature, one of the most important drivers of leaf $R_{d}$. On the other hand, water stress decreases the pool of leaf carbohydrates, which are the most important substrate for respiration. The aim of the present work was to determine the impact of water shortage on leaf $R_{d}$ in grapevine and understand the driving factors in modulating leaf $R_{d}$ response under plant water stress conditions. Water stressed vines had lower $R_{d}$ as the water shortage severity increased. $R_{d}$ was correlated with leaf temperature in well-watered vines. Instead, in water stressed vines, $R_{d}$ correlated with leaf soluble sugars. The decrease of leaf $R_{d}$ in water stressed vines was due to the decrease of leaf non-structural carbohydrate that, under water stress conditions, exerted a limiting effect on $R_{d}$.
\end{abstract}

Keywords: dark respiration; transpiration; water stress; plant physiology

\section{Introduction}

DOY, day of the year; $g_{s}$, stomatal conductance; $\Psi_{\mathrm{pd}}$, pre-dawn water potential; PPFD, photosynthetic photon flux density; $\mathrm{P}_{\mathrm{n}}$, net photosynthesis; $\mathrm{R}_{\mathrm{d}}$, dark respiration; $\mathrm{RWC}$, relative water content; $\mathrm{T}_{\text {leaf }}$, leaf temperature; $\mathrm{WS}$, water stress; $\mathrm{WW}$, well-watered.

Mitochondrial respiration (also referred to as dark respiration) is the controlled oxidation of reduced carbohydrates, producing $\mathrm{CO}_{2}$, reducing equivalents (NAD $(\mathrm{P}) \mathrm{H}$ and FADH2) and resulting in respiratory $\mathrm{O}_{2}$ consumption and ATP production [1]. In woody plants, between $25 \%$ and $75 \%$ of the $\mathrm{CO}_{2}$ fixed during photosynthesis can be released back to the atmosphere by plant respiration each year [2-5]. Respiration is utilized by plants to gain biomass (growth respiration) and to provide energy for all plant physiological processes that do not result in a net increase in plant dry matter, such as maintenance of ion gradients across membranes and the resynthesis of degraded organic compounds [6]. Plant tissues have a specific respiration rate and generally the highest is measured in the leaves, and it accounts for half of the plant respiration [2].

The amount of $\mathrm{CO}_{2}$ that is lost daily through dark respiration $\left(\mathrm{R}_{\mathrm{d}}\right)$ is related to environmental conditions [7] and in particular to temperature regimes $[4,8]$. The increase of temperature due to global warming can have a substantial impact on plant respiration $[9,10]$ and this may have consequences on plant ability to fix $\mathrm{CO}_{2}$ [11] and, ultimately, 
on agricultural crop productivity. Further, global warming is increasing daily mean temperature but also the frequency of extreme heat events. Furthermore, rainfall patterns are becoming more erratic exposing plants to recurrent drought stress that often reduce plant yield [11]. Drought stress and heat waves negatively impact several processes; plant growth is reduced during the early stages of water shortage [12], transpiration and photosynthesis is limited [13] and plant carbon partitioning to different organs is altered [14]. Water stress affects leaf $R_{d}$ too. Although the respiration rate is mainly limited by extreme temperatures, an important role is also played by several other factors; e.g., substrate availability, rate of the respiration processes, use of the respiratory products and the efficiency of the respiratory pathway $[2,15]$. Water stress increases leaf temperature due to a reduced leaf transpiration [16] and reduces the respiration substrate pool, due to a reduced photosynthetic assimilation [17]. This can cause $R_{d}$ to be limited by different factors according to the level of water availability.

In literature, there is poor consensus on the effect of water shortage on plant respiration [18]. Under water stress, respiration was reported to decrease [19-25], or to be almost unaffected [26,27] or even to increase [28-30]. Moreover, a biphasic response of respiration in plants with different water content was proposed: $R_{d}$ decreases when the water stress is mild (soil RWC $<50 \%$ ) and it increases when the water stress was more severe [18].

In grapevine, several studies reported that $R_{d}$ decreased as water stress rose [3,31-33]. However, Perez-Martin et al. [34] observed a consistent increase in respiration due to water shortage stress and Gomez-del-Campo et al. [14] reported an initial increase in night respiration and subsequent decrease as the water stress became more severe. Indeed, considering that water stress causes consistent variation in several factors affecting $R_{d}$, such as leaf temperature and carbohydrate availability [35], our hypothesis was that dark respiration variation during water stress can be caused by the indirect effect of water stress on leaf temperature and leaf carbohydrate status rather than to the water stress itself.

The aim of the present work was to determine the effect of soil water deprivation on leaf $R_{d}$. We focused our research on determining the role of leaf temperature and leaf carbohydrate content in $R_{d}$ regulation during water stress in grapevines.

\section{Results}

\subsection{Water Deprivation and Gas Exchange over the Experiment}

Net photosynthesis $\left(\mathrm{P}_{\mathrm{n}}\right)$ and stomatal conductance $\left(\mathrm{g}_{\mathrm{s}}\right)$ decreased during water stress from DOY 182 to DOY 186 (Figure 1A,B).

Upon re-watering (DOY 187), $P_{n}$ and $g_{s}$ were similar between WS and WW vines except at DOY 188 when the WS treatment had higher $P_{n}$ and $g_{s}$ than the WW vines. $\Psi_{\text {stem }}$ in WS vines decreased during water stress up to $-1.5 \pm 0.04 \mathrm{MPa}$ and reached values like the WW treatment soon after re-watering (Figure 1C). In WW vines, $\Psi_{\text {stem }}$ ranged between $-0.52 \pm 0.01$ and $-0.78 \pm 0.06 \mathrm{MPa}$.

At midday, leaf dark respiration $\left(\mathrm{R}_{\mathrm{d}}\right)$ was significantly lower in WS vines than in WW vines starting from DOY 182 until DOY 188 (Figure $2 A$ ). $R_{d}$ at 4:00 a.m. was significantly lower in WS leaves when compared with WW vines between DOY 186 and DOY 189. At midday, leaf temperature $\left(\mathrm{T}_{\text {leaf }}\right)$ was higher in WS than in WW on DOY 181 and 182 and between DOY 185 and DOY 186 (Figure 2B).

On DOY 183 and 188, $\mathrm{T}_{\text {leaf }}$ was higher in WW leaves in comparison with WS leaves. At 4:00 a.m., $\mathrm{T}_{\text {leaf }}$ was similar in WW and WS leaves during the entire experimental period. Water potential at pre-dawn $\left(\Psi_{\text {pd }}\right)$ was higher in WW than in WS between DOY 183 and 186 (Figure 2C). In WS, $\Psi_{\mathrm{pd}}$ ranged between $-0.04 \pm 0.001 \mathrm{MPa}$ and $-0.87 \pm 0.05 \mathrm{MPa}$. 


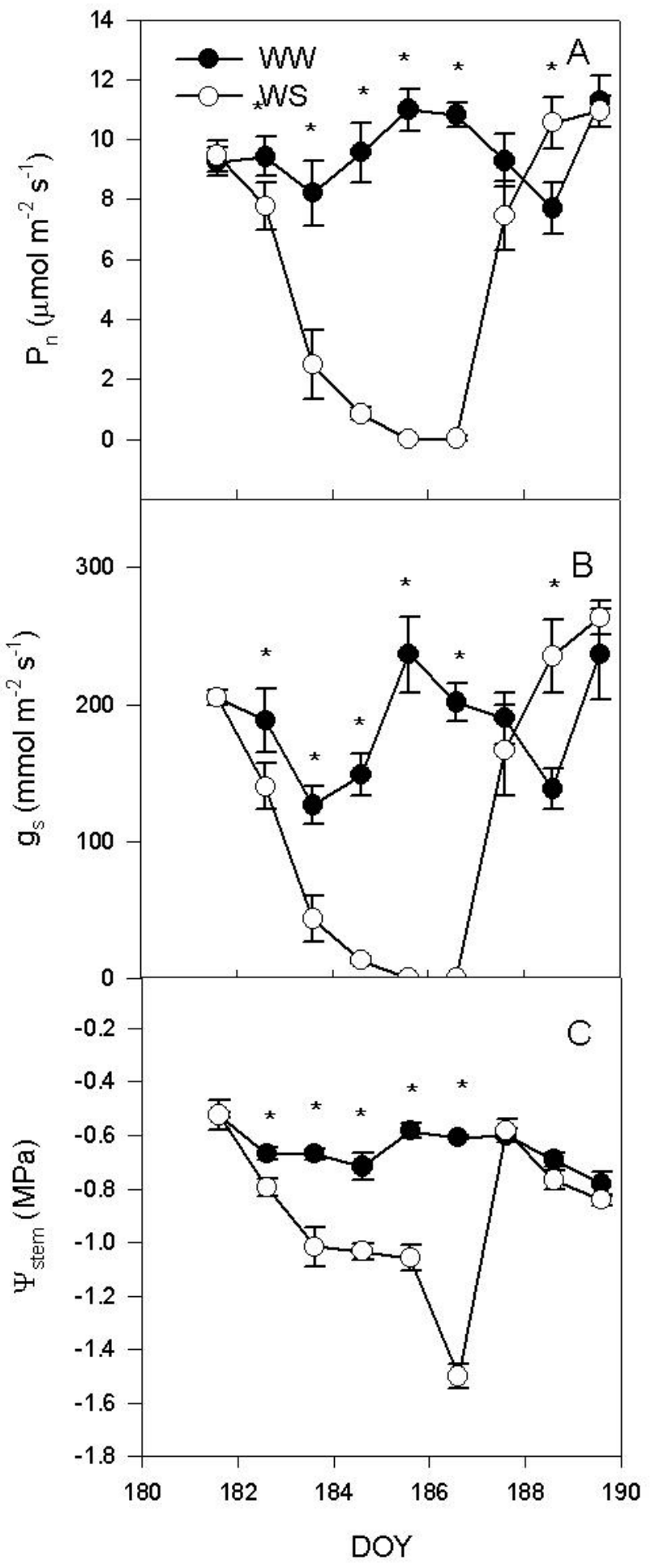

Figure 1. (A) net photosynthesis $\left(P_{n}\right),(B)$ stomatal conductance $\left(g_{s}\right)$, and $(C)$ stem water potential at midday $\left(\Psi_{\text {stem }}\right)$ recorded on mature leaves of well-watered $(\mathrm{WW})$ and water stress vines (WS) during the experiment. Each point is the mean of six vines \pm SE. Points marked by asterisk are different per $p<0.05$ (t-test). 


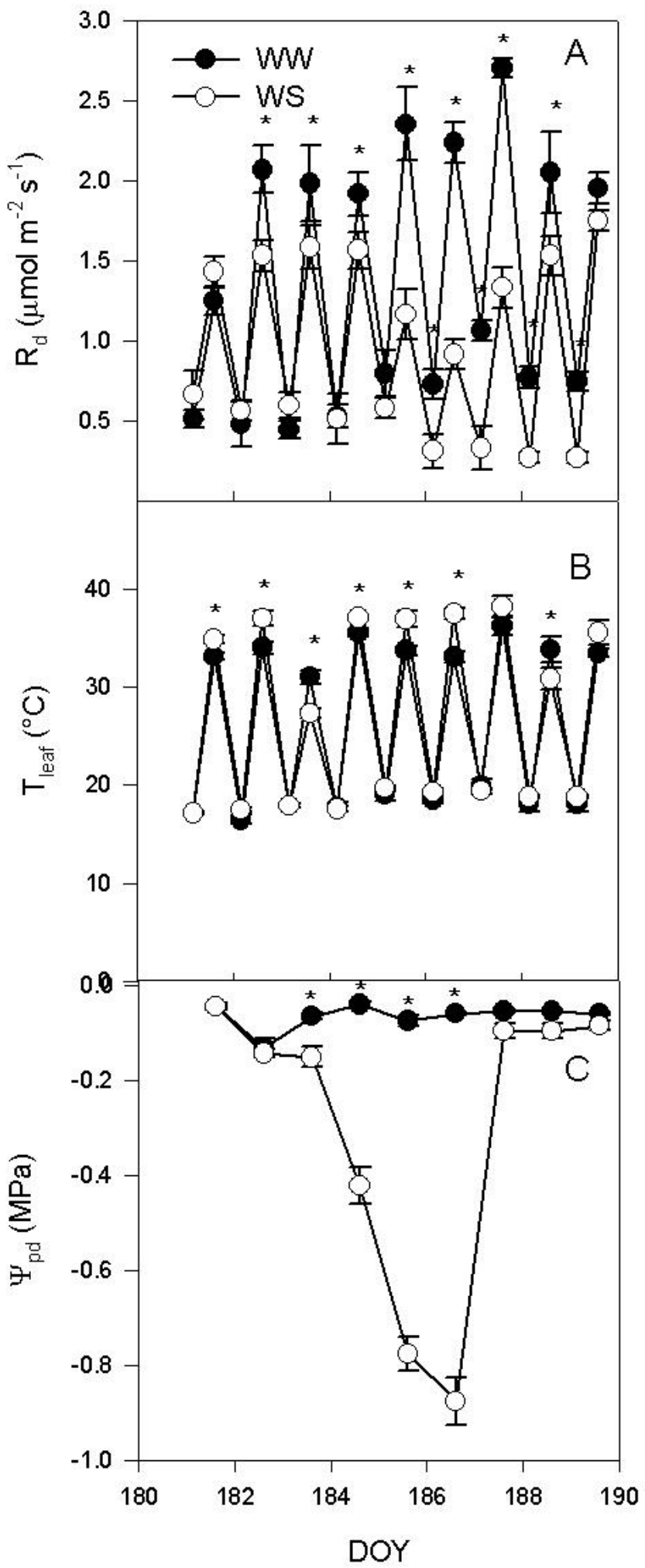

Figure 2. (A) Dark respiration $\left(\mathrm{R}_{\mathrm{d}}\right)$, (B) leaf temperature $\left(\mathrm{T}_{\text {leaf }}\right)$ at 4:00 a.m. and midday, and (C) predawn water potential $\left(\Psi_{\mathrm{pd}}\right)$ recorded on mature leaves of well-watered $(\mathrm{WW})$ and water stressed vines (WS) during the experiment. Each point is the mean of six vines \pm SE. Points marked by asterisk are different per $p<0.05$ ( $t$-test).

In leaves, soluble sugars were lower in WS than in WW at midday on DOY 185 and between DOY 186 and DOY 187 (Figure 3A). 


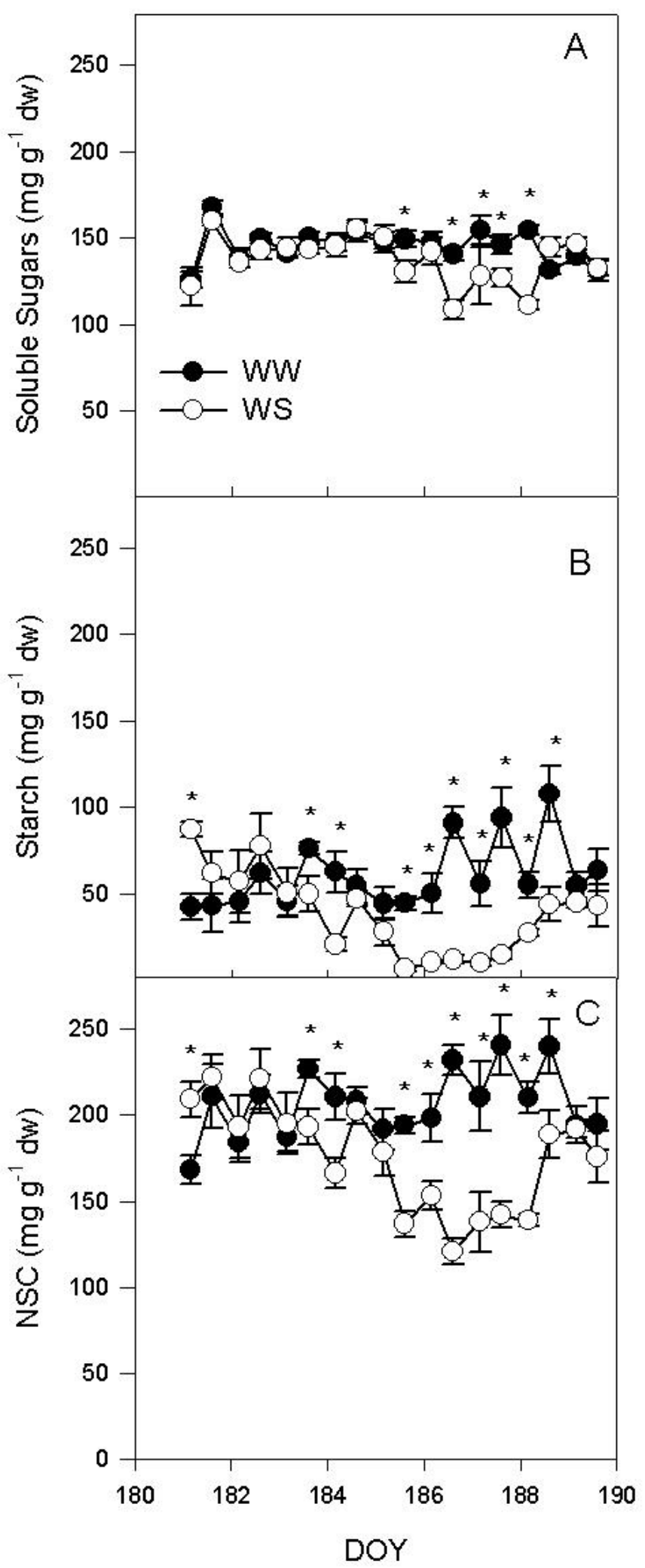

Figure 3. (A) soluble sugars, (B) starch and (C) non-structural carbohydrates (NSC) measured on mature leaves of well-watered (WW) and water stressed vines (WS) during the experiment. Each point is the mean of six vines \pm SE. Points marked by asterisk are different per $p<0.05$ ( $t$-test). 
Starch was lower in WS than in WW treatment between midday on DOY 183 and at 4:00 a.m. on DOY 184 and between midday on DOY 185 and midday in DOY 188 (Figure 3B). Non-structural carbohydrates (NSC) were lower in WS than in WW treatments between midday at DOY 183 and at 4:00 a.m. at DOY 184 and between midday on DOY 185 and midday on DOY 188 (Figure 3C).

\section{2. $R_{d}$ Regression with $T_{\text {leaf }}$ in $W W$ Vines}

There was a positive regression between $R_{d}$ and $T_{\text {leaf }}$ at midday in $W W$ vines $\left(R^{2}=0.38\right.$, $p<0.001)$, while in WS vines the regression, thought significant, was negative $\left(R^{2}=0.12\right.$, $p<0.01$ ) (Figure 4A)

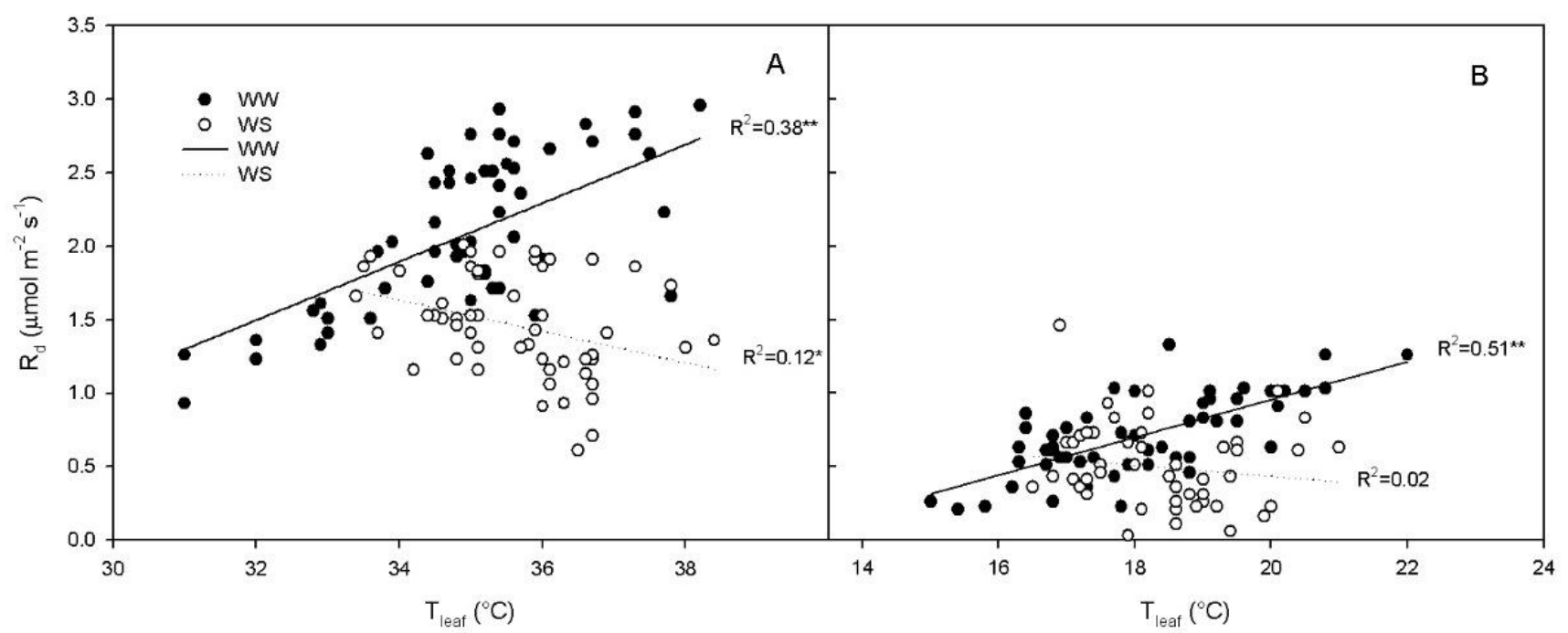

Figure 4. Relationship between leaf dark respiration $\left(R_{d}\right)$ and leaf temperature $\left(T_{\text {leaf }}\right)$ in wellwatered (WW) and water stressed (WS) vines at (A) midday $\left(\mathrm{y}=-4.87+0.20 \mathrm{x}, \mathrm{R}^{2}=0.38 p<0.0001\right.$; $\mathrm{y}=5.26-0.10 \mathrm{x}, \mathrm{R}^{2}=0.12 p=0.01$, respectively) and $(\mathbf{B})$ at $4: 00$ a.m. $\left(\mathrm{y}=-1.61+0.12 \mathrm{x}, \mathrm{R}^{2}=0.51\right.$ $p<0.0001 ; \mathrm{y}=1.20-0.04 \mathrm{x}, \mathrm{R}^{2}=0.02 p=0.29$, respectively). Regressions not statistically significant are represented as dot-lines. ${ }^{*}$ indicates $p<0.05 ;{ }^{* *}$ indicates $p<0.0001$.

At 4:00 a.m., there was a linear, positive regression between $R_{d}$ and $T_{\text {leaf }}$ in $W W$ vines $\left(\mathrm{R}^{2}=0.51, p<0.001\right)$, while in WS vines the regression was not significant $\left(\mathrm{R}^{2}=0.02\right.$, $p=0.29$ ) (Figure 4B).

\subsection{Rd Regression with Soluble Sugars in WS Vines}

A positive regression was also reported between $R_{d}$ and leaf soluble sugars at midday in WS vines $\left(\mathrm{R}^{2}=0.27, p<0.001\right)$, while in WW vines the regression was not significant $\left(\mathrm{R}^{2}=0.06, p=0.07\right)$ (Figure $\left.5 \mathrm{~A}\right)$.

At 4:00 a.m., there was a linear, positive regression between $R_{d}$ and leaf soluble sugars in the WS treatment $\left(\mathrm{R}^{2}=0.27, p<0.001\right)$, while in WW treatment the regression was not significant $\left(R^{2}=0.04, p=0.15\right)$ (Figure $5 B$ ). 


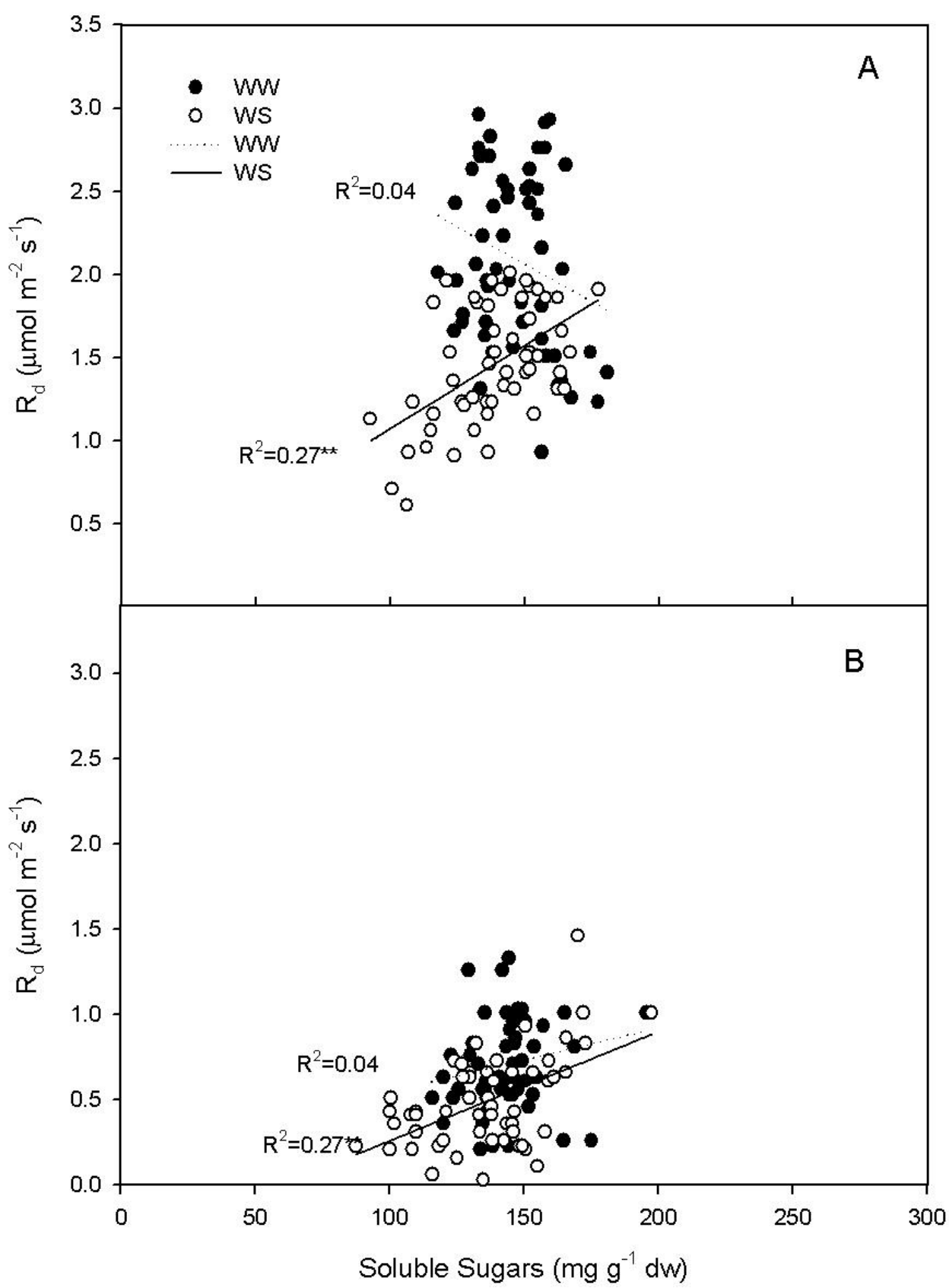

Figure 5. Relationship between leaf dark respiration $\left(\mathrm{R}_{\mathrm{d}}\right)$ and leaf soluble sugars in well-watered $(\mathrm{WW})$ and water stressed (WS) vines at $(\mathrm{A})$ midday $\left(\mathrm{y}=3.40-8.87 \mathrm{x}, \mathrm{R}^{2}=0.06 p=0.07 ; \mathrm{y}=0.07+\right.$ $10.01 \mathrm{x}, \mathrm{R}^{2}=0.27 p<0.0001$, respectively) and (B) at 4:00 a.m. $\left(\mathrm{y}=0.17+3.75 \mathrm{x}, \mathrm{R}^{2}=0.04 p=0.15\right.$; $\mathrm{y}=-0.37+6.39 \mathrm{x}, \mathrm{R}^{2}=0.27 p<0.0001$, respectively). ${ }^{*}$ indicates $p<0.05 ; * *$ indicates $p<0.0001$.

\subsection{Relationship between $R d, \Psi_{p d}$ and Non-Structural Carbohydrates}

In WS vines, a relationship between $R_{d}$ at midday and $\Psi_{p d}\left(R^{2}=0.30, p<0.001\right)$ was evidenced by a linear regression (Figure $6 \mathrm{~A}$ ) and, though barely significant, the linear regression was reported also with data recorded at 4:00 a.m. $\left(R^{2}=0.11, p=0.04\right)$ (Figure $6 B$ ). 


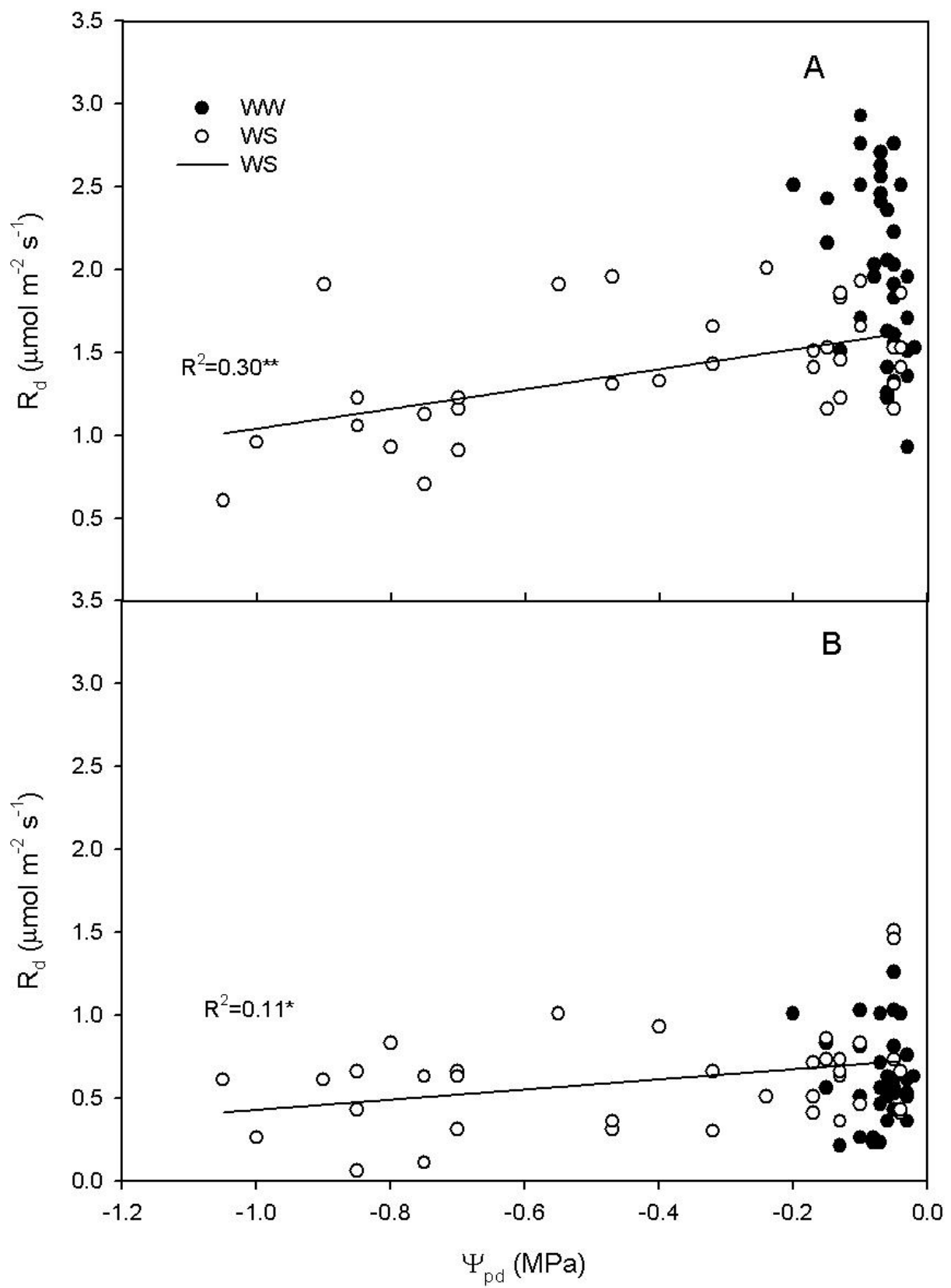

Figure 6. Relationship between leaf dark respiration $\left(R_{d}\right)$ and pre-dawn water potential $\left(\Psi_{\text {pd }}\right)$ in water stressed (WS) vines at $(\mathbf{A})$ midday $\left(\mathrm{y}=1.64+0.59 \mathrm{x}, \mathrm{R}^{2}=0.30 p<0.0001\right)$ and $(\mathbf{B})$ at 4:00 a.m. $\left(\mathrm{y}=0.73+0.31 \mathrm{x}, \mathrm{R}^{2}=0.11 p=0.04\right)$ during water stress from DOY 181 to DOY 187. * indicates $p<0.05 ;{ }^{* *}$ indicates $p<0.0001$.

In the WS treatment, a relation between leaf NSC at midday and $\Psi_{\mathrm{pd}}$ was described by a linear regression $\left(\mathrm{R}^{2}=0.59, p<0.001\right)$ (Figure 7A), and reported between leaf NSC at 4:00 a.m. and $\Psi_{p d}\left(R^{2}=0.17, p=0.011\right)$ (Figure 7B). 


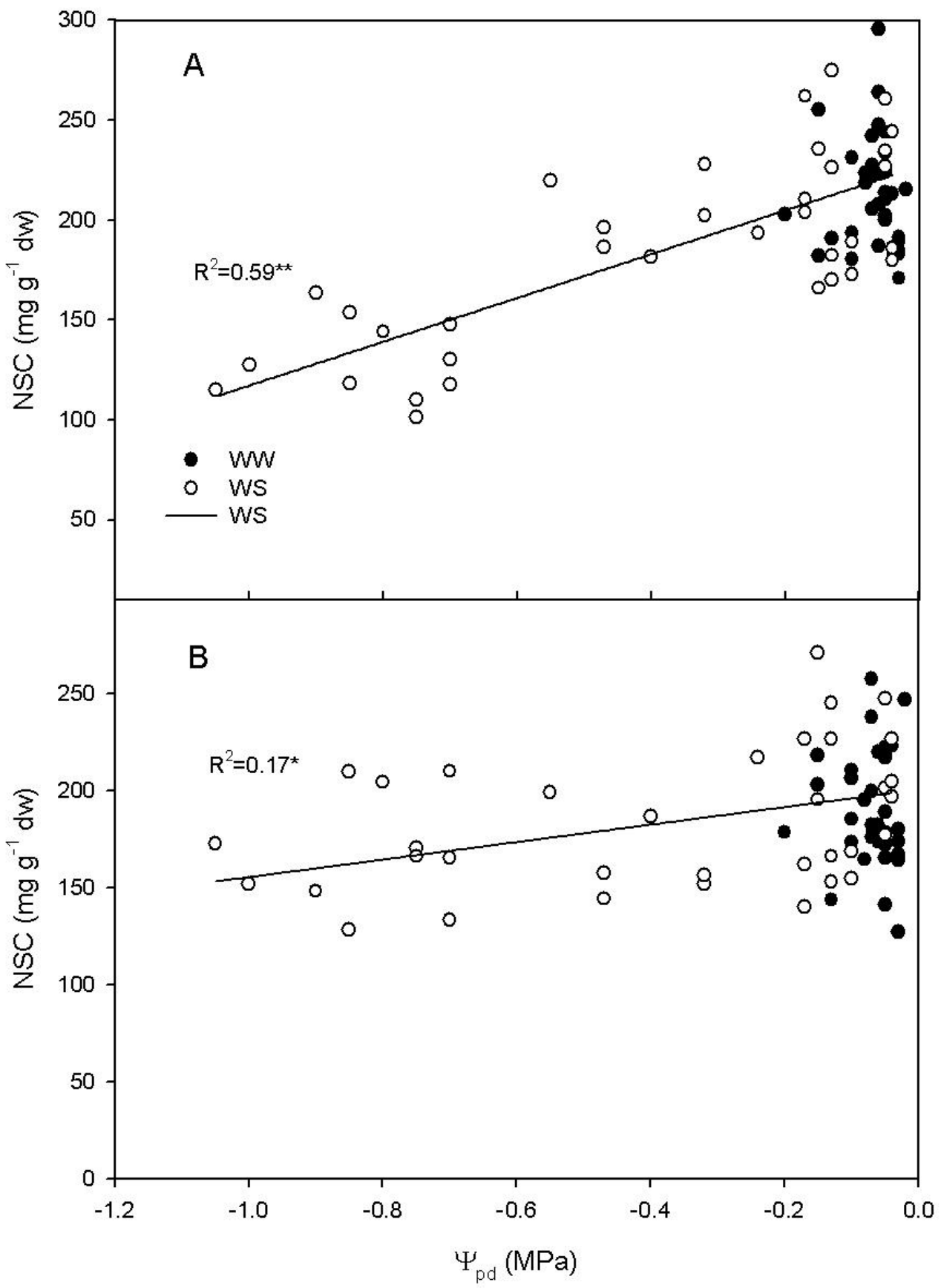

Figure 7. Relationship between non-structural carbohydrates (NSC) and pre-dawn water potential $\left(\Psi_{\mathrm{pd}}\right)$ in water stressed (WS) vines at $(\mathbf{A})$ midday $\left(\mathrm{y}=0.23+0.11 \mathrm{x}, \mathrm{R}^{2}=0.59 p<0.0001\right)$ and at $(\mathbf{B}) 4: 00$ a.m. $\left(\mathrm{y}=0.20+0.04 \mathrm{x}, \mathrm{R}^{2}=0.17 p=0.011\right)$ during water stress from DOY 181 to DOY 187. * indicates $p<0.05 ;{ }^{* *}$ indicates $p<0.0001$.

\section{Discussion}

The withholding of the irrigation induced a rapid decrease in $\Psi_{\text {stem }}$ that caused a complete stomata closure and a consequent severe reduction of the photosynthetic activity on DOY 185 (Figure 1). During the water stress, $R_{d}$ was particularly reduced at midday (Figure 2A). The lower $R_{d}$ measured at midday was inconsistent with the higher temperature recorded in WS leaves when compared to the WW ones (Figure 2A,B). In the condition of reduced water availability, as indicated by the $\Psi_{\mathrm{pd}}$ (Figure 2C), there was a limited leaf transpiration and thermoregulation capacity. WS vines had lower soluble sugar content than WW vines (Figure 3A). Instead, the effect of the water stress was more evident 
on starch content, which decreased during the early stages of the water stress, mirroring the dynamic of leaf photosynthesis. Overall, NSC decreased as consequence of water stress.

The major environmental driver of $R_{d}$ is temperature [8]. In our experiment this was true in well-watered plants, and, in fact, $R_{d}$ was positively correlated with leaf temperature $\left(\mathrm{T}_{\text {leaf }}\right)$ when measured at midday and at 4: 00 a.m. (Figure 4). Contrarily, in WS vines there was no positive regression (Figure 4) between $R_{d}$ and $T_{\text {leaf }}$, indicating that, under WS condition, leaf temperature was not the limiting factor driving $R_{d}$. This does not mean that temperature is not influencing $\mathrm{Rd}$, but that under WS the influence of temperature is less limiting than that of other factors and for this reason it explains a minimal percentage of the variability of the experimental sample. These results are to some extent in disagreement with those of Escalona et al. [3] which reported similar respiratory quotient in well-watered and leaves of vines subject to mild water stress (WS was set in order to keep gs $>75 \mathrm{mmol} \mathrm{m}^{-2} \mathrm{~s}^{-1}$ ). In our experiment, the WS treatment reached complete stomatal closure and $R_{d}$ was significantly correlated to leaf soluble sugars. However, such regression was not significant in the leaves of the WW treatment (Figure 5). This result suggests that under water stress the limiting factor for $R_{d}$ is represented by the amount of total carbohydrates available as substrate for respiration. Contrarily, under WW conditions leaf temperature plays a more significant role in limiting respiration. This accounts also for the slower recovery of $R_{d}$ after re-watering when compared with the recovery of $P_{n}$ and $g_{s}$ (Figures 1 and 2). The slow recovery of $R_{d}$ was like the dynamic of the recovery of soluble sugar content that slightly preceded that of starch in the leaf. The decrease of NSC in leaves during water stress agrees with what was previously reported in grapevine [36], but it is in contrast with what has been reported in Eucalyptus saligna, in which starch content increased during the early stages of water stress [37].

In our experiment, $R_{d}$ at midday significantly decreased as the $\Psi_{\text {pd }}$ became more negative, while no regression was evidenced at 4:00 a.m. (Figure 6). The same trend was observed for NSC; at midday, NSC significantly decreased as the $\Psi_{\text {pd }}$ became more negative, but, at 4:00 a.m., NSC slightly decreased during the water stress period (Figure 7). This indicates that $R_{d}$ progressively decreased as the water availability decreased, in accordance with previous works [3,31-33]. Although, in such studies this relationship was not fully explained [14,31-33]. Escalona et al. [3] speculated that $R_{d}$ reduction in roots and stems was linked to a reduced $Q_{10}$ related to the decrease of carbohydrate export from the leaves. Our experiment demonstrated that the reduction of leaf $R_{d}$ over $\Psi_{p d}$ was related to the dynamic of NSC content in the leaf, that decreased over the water stress period. The decrease of NSC during the water stress was more consistent at midday than at 4:00 a.m. and this explains the weaker decrease of $\mathrm{R}_{\mathrm{d}}$ during water stress recorded at 4:00 a.m. In particular, the natural daily variation in NSC and the effect of water stress in reducing the NSC daily variation due to the reduced photosynthetic activity, could explain the contradictory results reported in literature. Indeed, respiration was reported to decrease [19-25] or to be almost unaffected [26,27] or even to increase [28-30] under water stress. Our results indicates that the reduction of leaf $R_{d}$ occurs when the water stress induces a significant reduction of NSC, limiting $R_{d}$. If NSC are not reduced, the increase of leaf temperature induced by the reduction in leaf transpiration can cause an increase of $R_{d}$, juxtaposing the indirect effect of water stress on $R_{d}$. Furthermore, these data suggest that the combination of different time of measurement (dawn vs. midday) with water stress severity and the daily dynamic of leaf carbohydrate accumulation, area all influencing the leaf $\mathrm{R}_{\mathrm{d}}$.

\section{Materials and Methods}

\subsection{Plant Material}

The experiment was carried out in 2015 in an outdoor area of the Department of Agricultural, Food and Environmental Sciences, University of Perugia, located in the urban area of the city of Perugia, central Italy (43 $10^{\prime} 30^{\prime \prime} \mathrm{N} 12^{\circ} 39^{\prime} 45^{\prime \prime} \mathrm{E}, 405 \mathrm{~m}$ a.s.l). Twelve $60 \mathrm{~L}$ pots were filled with loamy soil having a field capacity of $30.2 \%$ \{(volume water/volume soil) $\times 100\}$ and a wilting point of $16.7 \%$. Each pot contained a 5-year- 
old vine of cv. Sangiovese (clone VCR30, grafted on 1103 Paulsen). Vines were winter spur-pruned leaving three spurs per vine carrying two buds each. During vine growth, developing shoots were directed upright using suitable stakes. Pots were maintained at field capacity throughout the experiment by an automated water-supply system providing water to each pot for $1 \mathrm{~min}$ three times per day $(08: 00 \mathrm{~h}, 13: 00 \mathrm{~h}$ and 18:00 h, $6 \mathrm{~L}$ per vine per day).

On six vines (WS), irrigation was withheld on 31 June (DOY 182) to 5 July (DOY 186). On 6 July (DOY 187) irrigation was resumed. The remaining vines were kept well irrigated throughout the whole experiment (WW).

\subsection{Gas Exchange}

Stomatal conductance $\left(g_{s}\right)$ and net photosynthesis $\left(P_{n}\right)$ measurements were carried out on fully expanded fully mature leaves grown between the 4 th and the 10th node. Measurements were performed between 12:00 a.m. and 1:00 p.m., from 30 June until 8 July on one representative leaf per vine on six vines per treatment $(n=6)$ using an open gas exchange system (ADC-System, LCA-3, Hoddesdon, UK) equipped with a Parkinson leaf chamber (window size of $11.2 \mathrm{~cm}^{2}$ ). Measurements were conducted under saturating sun light conditions (PPFD $>1200 \mu \mathrm{mol}$ photons $\left.\mathrm{m}^{-2} \mathrm{~s}^{-1}\right)$. Dark respiration $\left(\mathrm{R}_{\mathrm{d}}\right)$ was measured at 4:00 a.m. at night (complete darkness, PPFD $=0 \mu \mathrm{molm}{ }^{-2} \cdot \mathrm{s}^{-1}$ ) and at midday at ambient $\left[\mathrm{CO}_{2}\right]$. At midday leaves were covered by an aluminium foil $15 \mathrm{~min}$ before enclosure in the leaf chamber. Leaves were then sampled for non-structural carbohydrate determination.

\subsection{Water Potential Measurements}

On the same leaves used for gas exchange, leaf water potential was measured by a pressure chamber (Soilmoisture Corp, Santa Barbara, CA, USA). Stem water potential $\left(\Psi_{\text {stem }}\right)$ was measured over the same days and daytime of gas exchange on each vine on one mature leaf that had been wrapped in plastic film and aluminium foil $2 \mathrm{~h}$ prior to the measurements. Water potential values measured at 4:00 a.m. are reported as pre-dawn water potential $\left(\Psi_{\mathrm{pd}}\right)$.

\subsection{Non-Structural Carbohydrate Determination}

Leaves used for gas exchange $(n=6)$ were immediately placed in liquid nitrogen and then stored in a freezer at $-80 \mathrm{C}^{\circ}$. Then, the material was weighted and lyophilized (LIO5P, 5Pascal, Trezzano, Italy). Lyophilized material was weighted (dry weight) and grinded (MF10, IKAlabortechnik, Staufen, Germany). $0.01 \mathrm{~g}$ of leaf powder were placed in $15 \mathrm{~mL}$ tubes and added with a solution of ethanol $80 \%$ and placed in a warm bath with temperature set at $80 \mathrm{C}^{\circ}$ for $1 \mathrm{~h}$. After $10 \mathrm{~min}$ of centrifugation at 10,000 rpm, $10 \mu \mathrm{L}$ of supernatant was sampled and used for the determination of alcohol soluble sugars by the anthrone method [38,39]. For starch determination, pellet material was then washed with sodium acetate buffer and then added with $0.5 \mathrm{~mL}$ of sodium acetate buffer. Tubes were placed in warm bath with temperature set at $80 \mathrm{C}^{\circ}$ for $1 \mathrm{~h}$. One millilitre of solution of amyloglycosidase and $\alpha$-amylase in $0.05 \mathrm{M}$ sodium acetate buffer was added as described by Chow and Landhäusser (2004) [40] and bath temperature was set at $50 \mathrm{C}^{\circ}$. Soluble sugar content was then measured on the supernatant by the anthrone method as previously described.

\subsection{Statistical Analysis}

Data were analysed by linear and non-linear regression analysis using Sigmaplot 8.0 (SystatSoftware Inc., San Jose, CA, USA), and one way ANOVA was performed on dependent and independent variables in order to test the regression significance. Treatments were analysed by one-way ANOVA with significance level set at 0.05 and means were separated by Tukey's w-procedure at $p=0.05$. 


\section{Conclusions}

Water deprivation caused a decrease in grapevine transpiration and a consequent increase in leaf temperature and a consequent decrease in leaf dark respiration. Such reduction was related to the reduction of carbohydrates caused by the reduction of photosynthetic activity. Under water stress condition, the reduced availability of carbohydrates appears to play a larger role than temperature in limiting leaf dark respiration of grapevines.

Author Contributions: S.T. and A.P., conceived and planned the study. T.F., S.T. carried out the experiment, analyzed the data. S.T. wrote the first draft of the manuscript. T.F. managed the plants that were used in the study. S.P., P.S., F.G. and A.P. revised and edited the manuscript. A.P. helped in the analysis of the data, revised and edited the manuscript. All authors have read and agreed to the published version of the manuscript.

Funding: This research received no external funding.

Informed Consent Statement: Not applicable.

Data Availability Statement: Data available on request.

Conflicts of Interest: The authors declare no conflict of interest.

\section{References}

1. Siedow, J.A.; Day, D.A. Respiration and Photorespiration. In Biochemistry and Molecular Biology of Plants; Buchanan, B., Gruissem, W., Jones, R., Eds.; American Society of Plant Physiologists: Rockville, MD, USA, 2000; Volume 30, pp. 676-728.

2. Amthor, J.S. Respiration and Crop Productivity; Amthor, J.S., Ed.; Springer: New York, NY, USA, 1989.

3. Escalona, J.M.; Tomas, M.; Martorell, S.; Medrano, H.; Ribas-Carbo, M.; Flexas, J. Carbon Balance in Grapevines under Different Soil Water Supply: Importance of Whole Plant Respiration. Aust. J. Grape Wine Res. 2012, 18, 308-318. [CrossRef]

4. Kozlowski, T.T.; Kramer, P.J. Physiology of Woody Plants, 2nd ed.; Academic Press: New York, NY, USA, 1979.

5. Vogt, K. Carbon Budgets of Temperate Forest Ecosystems. Tree Physiol. 1991, 9, 69-86. [CrossRef] [PubMed]

6. Chiariello, N.R.; Mooney, H.A.; Williams, K. Growth, Carbon Allocation and Cost of Plant Tissues. In Plant Physiological Ecology; Pearcy, R.W., Ehleringer, J.R., Mooney, H.A., Rundel, P.W., Eds.; Springer: Dordrecht, The Netherlands, 1989 ; p. 533.

7. Wright, I.J.; Reich, P.B.; Atkin, O.K.; Lusk, C.H.; Tjoelker, M.G.; Westoby, M. Irradiance, Temperature and Rainfall Influence Leaf Dark Respiration in Woody Plants: Evidence from Comparisons across 20 Sites. New Phytol. 2006, 169, 309-319. [CrossRef] [PubMed]

8. Atkin, O.K.; Evans, J.R.; Ball, M.C.; Lambers, H.; Pons, T.L. Leaf Respiration of Snow Gum in the Light and Dark. Interactions between Temperature and Irradiance. Plant Physiol. 2000, 122, 915-924. [CrossRef] [PubMed]

9. Dusenge, M.E.; Duarte, A.G.; Way, D.A. Plant Carbon Metabolism and Climate Change: Elevated $\mathrm{CO}_{2}$ and Temperature Impacts on Photosynthesis, Photorespiration and Respiration. New Phytol. 2019, 221, 32-49. [CrossRef] [PubMed]

10. Ryan, M.G. Effects of Climate Change on Plant Respiration. Ecol. Appl. 1991, 1, 157-167. [CrossRef] [PubMed]

11. Fahad, S.; Bajwa, A.A.; Nazir, U.; Anjum, S.A.; Farooq, A.; Zohaib, A.; Sadia, S.; Nasim, W.; Adkins, S.; Saud, S.; et al. Crop Production under Drought and Heat Stress: Plant Responses and Management Options. Front. Plant Sci. 2017, 8, 1147. [CrossRef] [PubMed]

12. Osório, J.; Osório, M.L.; Chaves, M.M.; Pereira, J.S. Water Deficits Are More Important in Delaying Growth than in Changing Patterns of Carbon Allocation in Eucalyptus Globulus. Tree Physiol. 1998, 18, 363-373. [CrossRef] [PubMed]

13. Chaves, M.M.; Pereira, J.S.; Maroco, J.; Rodrigues, M.L.; Ricardo, C.P.; Osório, M.L.; Carvalho, I.; Faria, T.; Pinheiro, C. How Plants Cope with Water Stress in the Field. Photosynthesis and Growth. Ann. Bot. 2002, 89, 907-916. [CrossRef] [PubMed]

14. Gómez-Del-Campo, M.; Baeza, P.; Ruiz, C.; Lissarrague, J.R. Effects of Water Stress on Dry Matter Content and Partitioning in Four Grapevine Cultivars (Vitis Vinifera L.). J. Int. Sci. Vigne Vin 2005, 39, 1-10. [CrossRef]

15. Lambers, H.; Chapin, F.; Pons, T. Plant Physiological Ecology; Springer Inc.: New York, NY, USA, 1998.

16. Gates, D.M. Transpiration and Leaf Temperature. Annu. Rev. Plant Physiol. 1968, 19, 211-238. [CrossRef]

17. Patakas, A.; Nikolaou, N.; Zioziou, E.; Radoglou, K.; Noitsakis, B. The Role of Organic Solute and Ion Accumulation in Osmotic Adjustment in Drought-Stressed Grapevines. Plant Sci. 2002, 163, 361-367. [CrossRef]

18. Flexas, J.; Galmes, J.; Ribas-Carbo, M.; Medrano, H. The Effects of Water Stress on Plant Respiration. In Plant Respiration: From Cell to Ecosystem; Lambers, H., Ribas-Carbo, M., Eds.; Springer: Dordrecht, The Netherlands, 2005; pp. 85-94.

19. Brix, H. The Effect of Water Stress on the Rates of Photosynthesis and Respiration in Tomato and Loblolly Pine Seedlings. Physiol. Plant. 1962, 15, 10-20. [CrossRef]

20. Gonzalez-Meler, M.A.; Matamala, R.; Penuelas, J. Effects of Prolonged Drought Stress and Nitrogen Deficiency on the Respiratory $\mathrm{O}_{2}$ Uptake of Bean and Pepper Leaves. Photosynthetica 1997, 34, 505-512. [CrossRef]

21. Escalona, J.M.; Flexas, J.; Medrano, H. Stomatal and Non-Stomatal Limitations of Photosynthesis under Water Stress in FieldGrown Grapevine. Aust. J. Plant Physiol. 1999, 26, 421-433. [CrossRef] 
22. Haupt-Herting, S.; Klug, K.; Fock, H.P. A New Approach to Measure Gross $\mathrm{CO}_{2}$ Fluxes in Leaves. Gross $\mathrm{CO}_{2}$ Assimilation, Photorespiration, and Mitochondrial Respiration in the Light in Tomato under Drought Stress. Plant Physiol. 2001, 126, 388-396. [CrossRef]

23. Palta, J.A.; Nobel, P. Root Respiration for Agave Deserti: Influence of Temperature, Water Status and Root Age on Daily Patterns. J. Exp. Bot. 1989, 40, 181-186. [CrossRef]

24. Brown, K.W.; Thomas, J.C. The Influence of Water Stress Preconditioning on Dark Respiration. Physiol. Plant. 1980, 49, 205-209. [CrossRef]

25. Ghashghaie, J.; Duranceau, M.; Badeck, F.W.; Cornic, G.; Adeline, M.T.; Deleens, E. $\Delta 13 \mathrm{C}$ of $\mathrm{CO}_{2}$ Respired in the Dark in Relation to $\triangle 13 \mathrm{C}$ of Leaf Metabolites: Comparison between Nicotiana Sylvestris and Heliantus Annuus under Drought. Plant. Cell Environ. 2001, 24, 505-515. [CrossRef]

26. Lawlor, D.W. Water Stress Induced Changes in Photosynthesis, Photorespiration, Respiration and $\mathrm{CO}_{2}$ Compensation Concentration of Wheat. Photosynthetica 1976, 10, 378-387.

27. Loboda, T. Gas Exchange of Different Spring Cereal Genotypes under Normal and Drought Conditions. Photosynthetica 1993, 29, 567-572.

28. Shearman, L.L.; Esatin, J.D.; Sullivan, C.Y.; Kinbacher, E.J. Carbon Dioxide Exchange in Water-Stressed Maize Sorghum. Crop Sci. 1972, 12, 406-409. [CrossRef]

29. Upchurch, R.P.; Peterson, M.L.; Hagan, R.M. Effect of Soil-Moisture Content on the Rate of Photosynthesis and Respiration in Ladino Clover (Trifolium Repens L.). Plant Physiol. 1955, 30, 297-303. [CrossRef] [PubMed]

30. Zagdanska, B. Respiratory Energy Demand for Protein Turnover and Ion Transport in Wheat Leaves upon Water Demand. Physiol. Plant 1995, 95, 428-436. [CrossRef]

31. Schultz, H.R. Water Relations and Photosynthetic Responses of Two Grapevine Cultivars of Different Geographical Origin during Water Stress. Acta Hortic. 1996, 427, 251-266. [CrossRef]

32. Souza de, C.R.; Maroco, J.P.; dos Santos, T.; Rodrigues, M.; Lopes, C.; Pereira, J.; Chaves, M. Partial Rootzone Drying: Regulation of Stomatal Aperture and Carbon Assimilation in Field-Grown Grapevines (Vitis Vinifera Cv Moscatel). Funct. Plant Biol. 2003, 30, 653-662. [CrossRef]

33. Zufferey, V. Leaf Respiration in Grapevine (Vitis Vinifera 'Chasselas') in Relation to Environmental and Plant Factors. Vitis J. Grapevine Res. 2016, 55, 65-72. [CrossRef]

34. Perez-Martin, A.; Flexas, J.; Ribas-Carbò, M.; Bota, J.; Tomàs, M.; Infante, J.M.; Diaz-Espejo, A. Interactive Effects of Soil Water Deficit and Air Vapour Pressure Deficit on Mesophyll Conductance to $\mathrm{CO}_{2}$ in Vitis Vinifera and Olea Europaea. J. Exp. Bot. 2009, 60, 2391-2405. [CrossRef]

35. Azcon-Bieto, J.; Osmond, C.B. Relationship between Photosynthesis and Respiration. Plant Physiol. 1983, 71, 574-581. [CrossRef]

36. Dayer, S.; Prieto, J.; Galat, E.; JP, P. Leaf Carbohydrate Metabolism in Malbec. Aust. J. Grape Wine Res. 2016, 22, 115-123. [CrossRef]

37. Ayub, G.; Smith, R.A.; Tissue, D.T.; Atkin, O.K. Impacts of Drought on Leaf Respiration in Darkness and Light in Eucalyptus Saligna Exposed to Industrial-Age Atmospheric $\mathrm{CO}_{2}$ and Growth Temperature. New Phytol. 2011, 190, 1003-1018. [CrossRef]

38. Loewus, F.A. Improvement in Anthrone Method for Determination of Carbohydrates. Anal. Chem. 1952, 24, 219. [CrossRef]

39. Morris, D.L. Quantitative Determination of Carbohydrates with Drewood's Anthrone Reagent. Science 1948, 107, $254-255$. [CrossRef]

40. Chow, P.S.; Landhäusser, S.M. A Method for Routine Measurements of Total Sugar and Starch Content in Woody Plant Tissues. Tree Physiol. 2004, 24, 1129-1136. [CrossRef] 